\title{
Effect of Interlinkage on Agricultural Productivity - A Case Study in the District Of Burdwan of West Bengal
}

\author{
Dr. Nirmalendu Sarkar ${ }^{1}$, Dr. Santosh Kumar Dutta ${ }^{2}$, \\ Dr. Swapan Kumar Biswas ${ }^{3}$. \\ ${ }^{1}$ Dinabandhu Mahavidyalaya, Reader in Commerce, Bongaon, 24- Pgs(N), West Bengal, India. \\ ${ }^{2}$ Associate Professor in Economics, Hooghly Mohsin College,Hooghly, West Bengal, India. \\ ${ }^{3}$ Professors in Commerce (Ret.), Burdwan University, West Bengal, India.
}

\begin{abstract}
Agricultural activities are link with many other activities. Any sector of an economy cannot function in isolated manner. Rather how it integrates with other sectors determines its efficiency. In fact, we are very obsessed with systems concept. In a bigger system, every subsystem of it is not only interlinked but also interdependent. Agriculture is no exception. Agricultural productivity largely depends on irrigation system, communication network, power supply, marketing facilities, banking system and other infrastructural facilities. Ultimately outcome from agriculture would depend on how these elements are interlinked. Not only several factors but also their derivatives (linkage) also influence productivity. In this paper, we identify and explain different types of agricultural derivatives to enhance agricultural productivity of land i.e. effect of interlinkage on productivity.
\end{abstract}

Key Words: Interlinked, Agricultural Sector, Value Productivity, HIV Seeds, Derivatives, Respondent farmers, Dominant factors, Chemical Fertilizer Intensity, Cropping Intensity.

\section{Introduction:}

An interlinked deal is one in which two or more interdependent exchanges are simultaneously agreed upon. In agricultural sector we can identify four different markets, namely, land (lease) market, labour market, product market, and credit market which are more or less interlinked.

In the land market the owner of a plot of land is the seller who leases out lands to the small or landless farmers on the basis of certain contracts. Contract may be of different types.

In the labour market the workers sell their labour power to the owners of land and the workers in return get wages. Mode of wage payment and types of labour contract may vary from region to region and from one type of work to another.

In the product market the farmers (tenants) and the land-owners are the sellers. On the other hand, the buyers are usually the persons who are generally engaged in non-agricultural activities. By Credit market we mean a market where borrowing and lending of money could take place. In the credit market, lenders are suppliers and the borrowers are demanders.

In the contemporary literature we can identify atleast three types of interlinkage, e.g. i) Credit-Labour Interlinkage, ii) Credit-Product Interlinkage and iii) Credit-Tenancy Interlinkage.

i) Credit-Labour Interlinkage implies that the agricultural workers take loan from their employers.

ii) Credit-Product Interlinkage elicits the practice of taking loan by a producer (Land owner) from a trader (crop dealer) to whom he promises to sell at least a part of his product.

iii) Credit-Tenancy Interlinkage traces the system where tenant farmers take loan from the land-owners under varying terms and conditions.

A number of theoretical models have been developed to explain the existence and optimality of creditlabour contract ${ }^{1}$, credit-product contract ${ }^{2}$ and credit-tenancy contract ${ }^{3}$. It is generally argued that an interlinked system is better than a non-interlinked system. As regards the relation between interlinkage and agricultural productivity, there are two extreme opinions. According to Bhaduri the effect of interlinkage on productivity in a backward agriculture is negative. Second view (neo-classical view) is that the effect of interlinkage on productivity is positive. To resolve this dichotomy, an attempt is made here to test empirically the effect of interlinkage on productivity on the basis of information collected from the sample villages. Credit-tenancy interlinkage in our survey is practically non-existent and hence we are concentrating on credit-labour interlinkage and credit-product interlinkage. Both from theoretical and practical viewpoints, we may identify different types of determinants of agricultural productivity. A short list of them may be: -

i) land size. ii) crop variety (Traditional or HYV), iii) fertility of the soil, iv) irrigation facilities, v) use of chemical fertilizer and pesticides, vi) methood of cultivation, vii) labour attachment and interlinkage, viii) 
credit-product interlinkage, $x$ ) method of crop harvesting etc. It is very difficult to consider the total impact of all these factors simultaneously on agricultural productivity at a time.

\section{Methodology:}

There are six sub-divisions in Burdwan district. Among the sub-divisions, the people of two subdivisions viz. Asansol and Durgapur are highly engaged in industrial activities. Our study is mainly concerned with agricultural activities. For this reason these two subdivisions have not been considered for the study. As these two sub-divisions have been left out, the study mainly concerns with remaining four sub-divisions. Survey work of the study has been carried out with primary data pertaining to four villages from remaining four subdivisions taking one each from one sub-division. Considering easy accessibility and familiarity with the farmers, these four villages have been selected purposively. Not only that the villages also selected on the basis of certain characteristics. The village Nashigram is under Sadar (N) sub-division. The economy of the village is good with well communicated to the headquarters and other commercial places. The village Kashiyara under Sadar (S) sub-division is a village whose economy is good but communication is bad. The village Hapania is under Kalna sub-division having bad economic condition but communication of this village is good. The village Chhoto-Maliha under Katwa sub-division is a village whose economy is bad as well as communication is bad. All the farmers in our sample are classified into five categories i.e. marginal, small, semi-medium, medium and large. After selection of these villages purposively, we have taken different categories of farmers randomly from the sample villages. We have taken equal number of respondent farmers from all the sample villages for the study i.e. out of total 200 farmer-families 50 farmers from village Nasigram of Sadar (North) sub-division, another 50 farmers from village Kashiyara of Sadar (South) sub-division, 50 farmers from village Hapania located within Kalna sub-division and 50 farmers from village Chhoto-Maliha of Katwa sub-division. The field level information has been collected from the respondent farmers during the agricultural year 2005-2006.

\section{a)}

\section{Result and Discussion:}

Effect of credit-labour interlinkage on productivity:

Three alternative important explanations of credit-labou interlinkage are available in the present literature. Basu(1983) explains the emergence of interlinkage using the LRH(Lender's Risk Hypothesis). But Bardhan (1984) has applied the ERH (Employer's Risk Hypothesis) to explain the linkage. However, Gupta (1987) has explained this interlinkage with the help of the CEH (Consumption Efficiency Hypothesis) of Libenstein (1957).

It reveals from table-1 and table-2 that credit-labour interlikage is a common feature in all the sample villages. All categories of farmers excepting marginal farmers are involved with credit-labour interlinkage. From table- 2 it may be noted that this involvement increases with the increase in land size in all the sample villages.

Table-1

Credit-Labour Interlinkage in the sample villages
\begin{tabular}{|l|c|c|c|c|}
\hline \multicolumn{5}{|c|}{ villages } \\
\hline $\begin{array}{l}\text { Name of the village } \\
\text { No. of farmer families } \\
\text { in the village }\end{array}$ & Nashigram & Kashiyara & Hapania & $\begin{array}{l}\text { Chhoto- } \\
\text { Maliha }\end{array}$ \\
\cline { 2 - 5 } & 50 & 50 & 50 & 50 \\
\hline $\begin{array}{l}\text { No. of farmer families } \\
\text { involved in credit-labor } \\
\text { interlined (Percentage) }\end{array}$ & $24(48)$ & $26(52)$ & $14(28)$ & $18(36)$ \\
\hline
\end{tabular}

Source- Field Survey.

Table-2

Credit-Labour Interlinkage and Land Distribution

\begin{tabular}{|c|c|c|c|c|}
\hline \multirow{2}{*}{$\begin{array}{c}\text { Size Category of } \\
\text { Farmers } \\
\text { (in acres) }\end{array}$} & \multicolumn{4}{|c|}{$\begin{array}{c}\text { Number (Percentage) of farmer families in the size group involved in Credit- } \\
\text { Labour interlinked in the sample villages }\end{array}$} \\
\cline { 2 - 5 } & Nashigram & Kashiyara & Hapania & Chhoto-Maliha \\
\hline $\begin{array}{c}\text { Marginal } \\
\text { (Below 1.0 acre) }\end{array}$ & 0 & 0 & 0 & 0 \\
\hline $\begin{array}{c}\text { Small } \\
\text { (1.0 to } 2.0\end{array}$ & $(0)$ & $(0)$ & $(0)$ & $(0)$ \\
acre) & $(28.57)$ & $(33.33)$ & $(25)$ & 1 \\
& & & & $(8.33)$ \\
\hline
\end{tabular}


Effect Of Interlinkage On Agricultural Productivity - A Case Study In The District Of Burdwan Of

\begin{tabular}{|c|c|c|c|c|}
\hline $\begin{array}{l}\text { Semi - Medium } \\
(2.0 \text { acre to } 4.0 \\
\text { acre }\end{array}$ & $\begin{array}{c}2 \\
(22.22)\end{array}$ & $\begin{array}{c}6 \\
(60.0)\end{array}$ & $\begin{array}{c}6 \\
(31.58)\end{array}$ & $\begin{array}{c}6 \\
(35.29)\end{array}$ \\
\hline $\begin{array}{c}\text { Medium } \\
\text { (4.0 acre to } 10.0 \\
\text { acre) }\end{array}$ & $\begin{array}{c}9 \\
(81.82)\end{array}$ & $\begin{array}{c}12 \\
(60)\end{array}$ & $\begin{array}{c}5 \\
(71.43)\end{array}$ & $\begin{array}{c}9 \\
(75)\end{array}$ \\
\hline $\begin{array}{c}\text { Large } \\
\text { (10.0 acre \& } \\
\text { above })\end{array}$ & $\begin{array}{c}11 \\
(78.57)\end{array}$ & $\begin{array}{c}4 \\
(80)\end{array}$ & Does not arise & $\begin{array}{c}2 \\
(100)\end{array}$ \\
\hline
\end{tabular}

\section{Source- Field Survey. Note: Figures in are Brackets in percentages.}

In order to study the relation between credit-labour interlinkage and productivity statistically we have applied a two variable linear regression technique taking $\mathrm{y}=\mathrm{a}+\mathrm{bx}$, where $\mathrm{y}$ stands for the dependent variable and $\mathrm{x}$ stands for an independent variable.

We have done three sets of regression analysis where

i) $\mathrm{y}=$ yield per acre (in rupees)

$\mathrm{x}=$ interlinked employment as a percentage of total labour employed, interlinked employment

i.e. $\mathrm{x}=\longrightarrow \mathrm{x} 100$

total employement

ii) $y=$ fertilizer intensity (expenditure on chemical fertilizers per acre),

$\mathrm{x}=$ Interlinked employment as a percentage of total labour employed,

iii) $y=$ area cultivated under HYV crops as a percentage of gross sown area,

$\mathrm{x}=$ Interlinkaged employment as a percentage of total labour employed.

Regression equations have been formed separately for each village of our sample, taking all respondent farmers of different size groups together. Accordingly, we have separate regression analysis and results for each village of our sample.

Table-3 shows the simple linear regression results of yield per acre(in Rs.) on interlinked employment as a percentage of total labour employed. The regression coefficient of yield per acre on interlinked employment, as a percentage of total labour employed is positive in all the sample villages. Thus, on an average interlinked employment tends to increase productivity. However, the relation appears to be very weak and its impact seems to be limited as $R^{2}$ value is small in all the sample villages.

Table-3

Linear Regression results showing the Effect of Interlinked Credit-Labour Contract on Value roductivity (all respondent farmers of different size groups are taken together)

\begin{tabular}{|c|c|c|c|c|c|c|c|c|c|}
\hline Villages & $\begin{array}{c}\text { No of } \\
\text { farme } \\
\text { rs }\end{array}$ & $\begin{array}{l}\text { Mean } \\
\text { of } x\end{array}$ & $\begin{array}{l}\text { Mean } \\
\text { of } y\end{array}$ & $\begin{array}{l}\text { SD } \\
\text { of } x\end{array}$ & $\begin{array}{l}\text { SD. } \\
\text { of y }\end{array}$ & $\begin{array}{l}\text { Intercept } \\
\text { (SE) }\end{array}$ & $\begin{array}{l}\text { Slope } \\
\text { (SE) }\end{array}$ & $\mathrm{R}^{2}$ & $\underline{F}$ \\
\hline$\frac{\text { Nashigra }}{\underline{m}}$ & 50 & 8.267 & $\begin{array}{c}11094 \\
.84\end{array}$ & 174 & $\begin{array}{c}1193.69 \\
9\end{array}$ & $\begin{array}{c}10809 \\
(223.618 \\
6)\end{array}$ & $\begin{array}{c}34.531 \\
(0.71438 \\
)\end{array}$ & $\begin{array}{c}0.070 \\
4\end{array}$ & $\begin{array}{c}4.01376 \\
9\end{array}$ \\
\hline Kashiyara & 50 & 5.332 & $\begin{array}{c}18658 \\
.820\end{array}$ & 5.850 & $\begin{array}{c}2665.57 \\
8\end{array}$ & $\begin{array}{c}18533 \\
(519.834 \\
148)\end{array}$ & $\begin{array}{c}23.672 \\
(0.66400 \\
406) \\
\end{array}$ & $\begin{array}{c}0.002 \\
7\end{array}$ & $\begin{array}{c}0.14348 \\
74\end{array}$ \\
\hline Hapania & 50 & 4.123 & $\begin{array}{l}11761 \\
.060\end{array}$ & 7.349 & $\begin{array}{c}1785.59 \\
1\end{array}$ & $\begin{array}{c}11706 \\
(295.072 \\
33)\end{array}$ & $\begin{array}{c}13.402 \\
(0.33782 \\
3)\end{array}$ & 0.003 & $\begin{array}{c}0.15947 \\
84\end{array}$ \\
\hline $\begin{array}{l}\text { Chhoto- } \\
\text { Maliha }\end{array}$ & 50 & 3.480 & $\begin{array}{c}9590 . \\
9\end{array}$ & 5.148 & $\begin{array}{c}1182.98 \\
9\end{array}$ & $\begin{array}{c}9337.9 \\
(195.516 \\
45)\end{array}$ & $\begin{array}{c}72.714 \\
(1.52248 \\
1) \\
\end{array}$ & $\begin{array}{c}0.100 \\
1\end{array}$ & 5.89543 \\
\hline
\end{tabular}

Source- Field Survey

Notes: $y=$ yield per acre in Rs.(Dependent variable),

$x=$ interlinked employment as a percentage of total labour employed (Independent variable)

Result : Regression co-efficient is positive in all the sample villages, implying a direct relationship between productivity and interlinked employment. $\mathrm{R}^{2}$ value is small in all villages, implying a negligible role played by interlinked employment on value productivity. 
Table-4

Linear Regression results showing the Effect of Interlinked Credit-Labour Contract on Fertilizer ntensity (all respondent farmers of different size groups are taken together)

\begin{tabular}{|c|c|c|c|c|c|c|c|c|c|}
\hline Villages & $\begin{array}{l}\text { No.o } \\
\mathrm{f} \\
\text { farm } \\
\text { ers }\end{array}$ & $\begin{array}{c}\text { Mea } \\
n \\
\text { of } x\end{array}$ & $\begin{array}{l}\text { Mean } \\
\text { of } y\end{array}$ & $\begin{array}{l}\text { SD } \\
\text { of } x\end{array}$ & $\begin{array}{l}\text { SD. } \\
\text { of } y\end{array}$ & $\begin{array}{l}\text { Intercept } \\
\text { (SE) }\end{array}$ & $\begin{array}{c}\text { Slope } \\
\text { (SE) }\end{array}$ & $\mathrm{R}^{2}$ & $\underline{F}$ \\
\hline Nashigram & 50 & $\begin{array}{r}8.26 \\
7\end{array}$ & $\begin{array}{r}1238.9 \\
48\end{array}$ & $\begin{array}{r}9.17 \\
4\end{array}$ & $\begin{array}{r}442.2 \\
17\end{array}$ & $\begin{array}{r}1189.1 \\
(85.24472 \\
1)\end{array}$ & $\begin{array}{r}6.0303 \\
(0.432302 \\
)\end{array}$ & $\begin{array}{r}0.015 \\
6\end{array}$ & 9.796208 \\
\hline Kashiyara & 50 & $\begin{array}{r}5.33 \\
2\end{array}$ & $\begin{array}{r}1525.6 \\
72\end{array}$ & $\begin{array}{r}5.85 \\
0\end{array}$ & $\begin{array}{r}267.4 \\
27\end{array}$ & $\begin{array}{r}1501 \\
(51.95667 \\
86)\end{array}$ & $\begin{array}{r}4.6321 \\
(0.160338 \\
79)\end{array}$ & $\begin{array}{r}0.010 \\
3\end{array}$ & $\begin{array}{r}0.551581 \\
289\end{array}$ \\
\hline Hapania & 50 & $\begin{array}{r}4.12 \\
3\end{array}$ & $\begin{array}{r}1338.8 \\
51\end{array}$ & $\begin{array}{r}7.34 \\
9\end{array}$ & $\begin{array}{r}409.1 \\
93\end{array}$ & $\begin{array}{r}1379.2 \\
(66.66988 \\
)\end{array}$ & $\begin{array}{r}9.7822 \\
(0.472866 \\
)\end{array}$ & $\begin{array}{r}0.030 \\
9\end{array}$ & 1.689918 \\
\hline $\begin{array}{l}\text { Chhoto- } \\
\text { Maliha }\end{array}$ & 50 & $\begin{array}{r}3.48 \\
0\end{array}$ & $\begin{array}{r}1031.1 \\
41\end{array}$ & $\begin{array}{r}5.14 \\
8\end{array}$ & $\begin{array}{r}422.9 \\
71\end{array}$ & $\begin{array}{r}897.11 \\
(65.09463 \\
)\end{array}$ & $\begin{array}{r}38.515 \\
(2.79466)\end{array}$ & $\begin{array}{r}0.219 \\
7\end{array}$ & 14.92259 \\
\hline
\end{tabular}

\section{Source- Field Survey}

Notes: $y=$ fertilizer intensity (Expenditure of chemical fertilizer per acre which is the dependent variable). $x=$ interlinked employment as a percentage of total labour employed (Independent variable).

Result: The regression co-efficient is positive in all the sample villages, implying a direct relationship between fertilizer intensity and

Interlinked employment which implies a direct relationship between productivity and interlinked employment. Moreover, $\mathrm{R}^{2}$ value is small in all villages.

Table-4 presents the results of two variable linear regression of fertilizer intensity on interlinked employment. Here interlinked employment is taken as a percentage of total labour employed. If the value of regression coefficient is positive, then we can expect that credit-labour interlinkage will help to increase productivity. Here, in all the sample villages the results of regression coefficient are positive. It transpires from the preceding analysis that credit-labour interlinkage helps to increase productivity. However, the relation is very weak as $\mathrm{R}^{2}$ value is small in all the sample villages. As such the impact of the interlinkage may be very limited.

Table-5 similarly displays the results of two variable linear regression of area under HYV crops on interlinked employment. The area under HYV crops, here is taken as a percentage of gross sown area and interlinked employment has been calculated as a percentage of total labour employed. This case the value of regression co-efficient is positive for all the sample villages, implying that there is a direct relation between productivity and interlinked employment. The relation is direct, but weak as the pertinent $\mathrm{R}^{2}$ value is small for all the sample villages.

It reveals from the results of regression analysis presented in tables- 3, 4 and 5 that the effect of interlinked employment on productivity is positive in all the sample villages. However, in all cases $\mathrm{R}^{2}$ value is small. So, interlinked employment cannot be treated as an important explanatory variable of productivity. From the farmer's view point it may be observed that compared to total labour cost interlinked loan is negligible. The farmers do not like to advance more loans to workers as they usually depend on migrant labours during peak seasons.

\section{b) Effect of credit-product interlinkage on productivity:}

Apart from credit-labour interlinkage there is another type of interlikage which is mostly found in the agriculturally backward areas. This is the credit-product interlinkage, which is specially found when the producer takes loan from a particular trader to whom he remains obliged to sell at least a part of his product. Recently some theoretical models 4 have been developed to explain the existence and optimality of interlinked credit-product contract. It reveals from the data collected from our present field survey of four villages of West Bengal that credit product interlinkage is commonly found in all the villages. It is further observed that not only the small and marginal farmers but also the medium and large farmers are credit-linked with the traders. This observation, at the outset seems paradox as it obviously contradicts with the existing ideas and views expressed in contemporary theoretical literature. 
In almost contemporary theories, it is assumed that the small farmers are involved in credit-product interlinkage with the crop traders who are also landlord (large farmer). But in our survey we have observed that a trader who may be a third party but related to agriculture, is not necessarily a landlord, rather is a separate entity.

Information relating to Credit-Product Interlinkage that has been collected empirically are processed and presented in table-6. It transpires from the table- 6 that credit-product interlinkage is a common feature in all the sample villages. It is generally found in all the cases that some respondent farmer families are involved in credit-product interlinkage with the traders. The traders purchase crops (mainly paddy) from the farmers and some of the traders also sell chemical fertilizers, pesticides and some farm machineries to the farmers. The traders usually give loans to the farmers and the farmers repay the loans by selling crops to those traders. Thus they are involved usually with some particular farmers in such transactions. This relation often sustains and continues for years. In case of village Nashigram, out of 50 farmer families 25 families are involved in creditproduct interlinkage. Similarly, in case of village Kashiyara, out of 50 farmer families 25 families are involved in credit-product interlinkage. In the village Hapania this figure is 20 out of 50 and in the village Chhoto-Maliha it is 16 out of 50 . About 40 per cent and 32 per cent villagers are related to Credit-Product linkage respectively in village Hapania and Chhoto-Maliha. It reveals that in comparison to backward villages, more families are involved in credit-product interlinkage in advanced villages. The numbers of traders connected with the four villages are 14, 9, 11 and 6 respectively.

Table-5

Linear Regression results showing the Effect of Interlinked Credit-Labour Contract on Productivity of HYV Crops (all respondent farmers of different size groups are taken together)

\begin{tabular}{|c|c|c|c|c|c|c|c|c|c|}
\hline Villages & $\begin{array}{c}\text { No.of } \\
\text { farme } \\
\text { rs }\end{array}$ & $\begin{array}{l}\text { Mean } \\
\text { of } x\end{array}$ & $\begin{array}{c}\text { Mea } \\
n \\
\text { of } y\end{array}$ & $\begin{array}{l}\text { SD } \\
\text { of } x\end{array}$ & $\begin{array}{l}\text { SD. } \\
\text { of y }\end{array}$ & $\begin{array}{l}\text { Intercept } \\
\text { (SE) }\end{array}$ & $\begin{array}{l}\text { Slope } \\
\text { (SE) }\end{array}$ & $\mathrm{R}^{2}$ & $\underline{F}$ \\
\hline Nashigram & 50 & 8.267 & $\begin{array}{r}69.1 \\
99\end{array}$ & $\begin{array}{r}9.09 \\
9\end{array}$ & $\begin{array}{r}35.8 \\
59\end{array}$ & $\begin{array}{r}57.159 \\
(6.49805 \\
5)\end{array}$ & $\begin{array}{r}1.4565 \\
(0.16558 \\
05)\end{array}$ & $\begin{array}{r}0.13 \\
88\end{array}$ & $\begin{array}{r}8.54203 \\
4\end{array}$ \\
\hline Kashiyara & 50 & 5.332 & $\begin{array}{r}79.1 \\
80\end{array}$ & $\begin{array}{r}5.91 \\
8\end{array}$ & $\begin{array}{r}27.4 \\
14\end{array}$ & $\begin{array}{r}76.143 \\
(5.28599 \\
57) \\
\end{array}$ & $\begin{array}{r}0.5698 \\
(0.03955 \\
66) \\
\end{array}$ & $\begin{array}{r}0.01 \\
48\end{array}$ & $\begin{array}{r}0.79618 \\
35\end{array}$ \\
\hline Hapania & 50 & 4.123 & $\begin{array}{r}69.1 \\
99\end{array}$ & $\begin{array}{r}7.34 \\
9\end{array}$ & $\begin{array}{r}35.8 \\
59\end{array}$ & $\begin{array}{r}66.049 \\
(5.86161 \\
)\end{array}$ & $\begin{array}{r}0.7642 \\
(0.06782 \\
0)\end{array}$ & $\begin{array}{r}0.02 \\
45\end{array}$ & $\begin{array}{r}1.33111 \\
2\end{array}$ \\
\hline $\begin{array}{l}\text { Chhoto } \\
\text {-Maliha }\end{array}$ & 50 & 3.48 & $\begin{array}{r}25.0 \\
94\end{array}$ & $\begin{array}{r}5.14 \\
8\end{array}$ & $\begin{array}{r}27.3 \\
57\end{array}$ & $\begin{array}{r}23.796 \\
(4.75450 \\
1) \\
\end{array}$ & $\begin{array}{r}0.3728 \\
(0.07448 \\
6) \\
\end{array}$ & $\begin{array}{r}0.00 \\
49\end{array}$ & $\begin{array}{r}0.26097 \\
8\end{array}$ \\
\hline
\end{tabular}

\section{Source- Field Survey}

Notes: $y=$ area under HYV as a percentage of total GCA (Dependent variable) $x=$ interlinked employment as a percentage of total labour employed (Independent variable)

Result: The regression co-efficient is positive in all the sample villages, implying a direct relationship between productivity of HYV crops and interlinked employment which implies a direct relationship between productivity and interlinked employment. However, $\mathbf{R}^{\mathbf{2}}$ value is small in all villages.

Table-6

Interlinkage in Different Credit-Product Villages

\begin{tabular}{|l|c|c|c|c|}
\hline \multicolumn{5}{|c|}{ VILLAGES } \\
\hline Name of the village & Nashigram & Kashiyara & Hapania & Chhoto-Maliha \\
\hline No of Respondent Farmers & 50 & 50 & 50 & 50 \\
\hline $\begin{array}{l}\text { No. of farmer families involved in } \\
\text { credit labour interlinked }\end{array}$ & 25 & 25 & 20 & 16 \\
\hline $\begin{array}{l}\text { No. of traders connected with the } \\
\text { village }\end{array}$ & 14 & 9 & 11 & 6 \\
\hline
\end{tabular}

Source - Field Survey. 
Gangopadhay and Sengupta (1987) in their work as sume that the trader occupies a monopolistic position in the product market. But we have noted in all the entire four sample villages of this study that there are many traders and there exists a tacit competition among them. However, this observation is consistent with that of Bell and Srinivasan (1989) as they have assumed that there is free entry for trader(s) or monely-lenders i.e. a competition exists among the traders and money lenders. It is, therefore, pertinent to examine the extent of credit-product interlinkage among different size categories of farmers in the sample villages.

Table-7 clearly describes the extent of credit-product interlinkage found in different categories of farmers. Data stated in the table-7 reveals that in all the villages of our sample, the farmers possession of small land holdings have better credit-linked with the traders than that of large farmers. This is mainly due to the fact that the small farmers cannot purchase agricultural inputs like seeds, fertilizers etc. from the open market with ready cash as such they heavily depend on traders or crop dealers. But in most of the cases the large farmers can afford to purchase those inputs directly from traders with their own funds.

Another interesting feature, which may be noted from the data we complied from the field survey, is that even some of the large farmers who are able to purchase all agricultural inputs from the open market (i.e. they have free choice to buy from any trader's shop) with their own funds, also take loan from traders.

Thus large farmers are also involved in credit-product interlinkage specially to enjoy certain benefits e.g. 1 . Where communication becomes a constraint to sell crops, particularly during rainy season, the large farmers often take credit from traders either in cash or in kind.

2. During the busy season, the large farmers usually approach to the traders for credit to save their valuable time, which they have to spare for marketing the product, as they have to pay more attention to agricultural activities.

Table-7

Land Distribution and Credit-Product Interlinkage

\begin{tabular}{|c|c|c|c|c|}
\hline \multirow{2}{*}{$\begin{array}{l}\text { Size Category of } \\
\text { Farmers } \\
\text { (in acres) }\end{array}$} & \multicolumn{4}{|c|}{$\begin{array}{l}\text { Number (Percentage) of farmer families in the size group involved in } \\
\text { Credit-Product interlinked in the sample villages }\end{array}$} \\
\hline & Nashigram & Kashiyara & Hapania & Chhoto-Maliha \\
\hline $\begin{array}{l}\text { Marginal } \\
\text { (Below 1.0 acre) }\end{array}$ & $\begin{array}{c}6 \\
(66.67)\end{array}$ & $\begin{array}{c}1 \\
\text { (33.33) }\end{array}$ & $\begin{array}{c}6 \\
(50.00)\end{array}$ & $\begin{array}{c}3 \\
(42.86)\end{array}$ \\
\hline $\begin{array}{l}\text { Small } \\
(1.0 \text { acre to } 2.0 \\
\text { acre) }\end{array}$ & $\begin{array}{c}3 \\
(42.86)\end{array}$ & $\begin{array}{c}8 \\
(66.67)\end{array}$ & $\begin{array}{c}5 \\
(41.667)\end{array}$ & $\begin{array}{c}5 \\
(41.67)\end{array}$ \\
\hline $\begin{array}{l}\text { Semi - Medium } \\
\text { (2.0 acre to } 4.0 \\
\text { acre }\end{array}$ & $\begin{array}{c}7 \\
(77.78)\end{array}$ & $\begin{array}{c}4 \\
\text { (40.00) }\end{array}$ & $\begin{array}{c}7 \\
(36.84)\end{array}$ & $\begin{array}{c}4 \\
(23.53)\end{array}$ \\
\hline $\begin{array}{l}\text { Medium } \\
(4.0 \text { acre to } 10.0 \\
\text { acre) }\end{array}$ & $\begin{array}{c}6 \\
(54.54)\end{array}$ & $\begin{array}{c}11 \\
\text { (55.00) }\end{array}$ & $\begin{array}{c}2 \\
(28.57)\end{array}$ & $\begin{array}{c}4 \\
(8.33)\end{array}$ \\
\hline $\begin{array}{l}\text { Large } \\
\text { (10.0 acre \& } \\
\text { above) }\end{array}$ & $\begin{array}{c}3 \\
(21.43)\end{array}$ & $\begin{array}{c}1 \\
\text { (20.00) }\end{array}$ & Does not arise & $\begin{array}{c}0 \\
\text { (0) }\end{array}$ \\
\hline
\end{tabular}

Source- Field Survey. Note: Figures in are Brackets in percentages.

3. Where there is no permanent earning member in the farmer's family to meet regular family expenses; in such cases the farmers has to sell crops to collect cash, he may take loan from the trader instead of selling the crops at a lower price. In that situation credit-product interlinkage greatly benefits farmers.

4. Loan is usually interest free. This allures farmers to take loan from the traders. Now we intend to examine the effect (positive or negative) of credit-product interlinkage on productivity. For examining of this proposition here we have resorted to the two variable linear regression analysis (shown in table-8) taking yield value (Rupees) per acre as the dependent variable and interlinked loan (product-linked loan) as a percentage of total loan taken from all sources (interlinked loan) as the independent variable. It reveals from table- 8 that the regression coefficient is positive in all the sample villages, implying a direct (positive) relation between creditproduct interlinkage and productivity. However, $\mathrm{R}^{2}$ value is small in all the sample villages. This ensures that credit-product interlinkage has a positive contribution on productivity but its effect is not very strong. 
IV. Conclusion:

It has time and again been stated that agricultural productivity depends on a large number of factors besides fertility of land, which is no doubt, the dominant factor among all the factors. Not only these factors but also some derivatives of these factors also influence productivity in agriculture. An attempt has been made in this chapter to explain the impact of certain types of interlinkage (either credit-labour or credit-product) on agricultural productivity. From our empirical findings it appears that the effect of both

Table-8

Linear Regression results showing the Effect of Credit-Product Interlinkage on Agricultural Productivity (all respondent farmers of different size groups are taken together)

\begin{tabular}{|c|c|c|c|c|c|c|c|c|c|}
\hline Villages & $\begin{array}{l}\text { No.of } \\
\text { farme } \\
\text { rs }\end{array}$ & $\begin{array}{c}\text { Mea } \\
n \\
\text { of } x\end{array}$ & $\begin{array}{c}\text { Mean } \\
\text { of } y\end{array}$ & $\begin{array}{l}\text { SD } \\
\text { of } x\end{array}$ & $\begin{array}{l}\text { SD. } \\
\text { of y }\end{array}$ & $\begin{array}{l}\text { Intercept } \\
(\mathrm{SE})\end{array}$ & $\begin{array}{c}\text { Slope } \\
\text { (SE) }\end{array}$ & $\mathrm{R}^{2}$ & $\underline{F}$ \\
\hline Nashigram & 50 & $\begin{array}{c}1.20 \\
7\end{array}$ & $\begin{array}{c}11094.8 \\
4\end{array}$ & 2.22 & $\begin{array}{c}1193.6 \\
99\end{array}$ & $\begin{array}{c}11012 \\
(194.50529 \\
)\end{array}$ & $\begin{array}{c}68.732 \\
(1.2140 \\
18)\end{array}$ & $\begin{array}{c}0.011 \\
8\end{array}$ & $\begin{array}{c}0.632 \\
867\end{array}$ \\
\hline Kashiyara & 50 & $\begin{array}{c}0.86 \\
9\end{array}$ & $\begin{array}{c}18658.8 \\
20\end{array}$ & 1.232 & $\begin{array}{c}2665.5 \\
78\end{array}$ & $\begin{array}{c}18145 \\
(452.83200 \\
9)\end{array}$ & $\begin{array}{c}591.39 \\
(14.758 \\
907)\end{array}$ & $\begin{array}{c}0.074 \\
7\end{array}$ & $\begin{array}{l}3.989 \\
247\end{array}$ \\
\hline Hapania & 50 & $\begin{array}{c}0.53 \\
5\end{array}$ & $\begin{array}{c}11761.0 \\
60\end{array}$ & 0.738 & $\begin{array}{c}1785.5 \\
91\end{array}$ & $\begin{array}{c}11754 \\
(318.4521)\end{array}$ & $\begin{array}{c}13.945 \\
(0.3778 \\
13)\end{array}$ & $\begin{array}{c}0.000 \\
03\end{array}$ & $\begin{array}{c}0.001 \\
59\end{array}$ \\
\hline $\begin{array}{r}\text { Chhoto- } \\
\text { Maliha }\end{array}$ & 50 & $\begin{array}{c}0.52 \\
5\end{array}$ & 9590.90 & 0.984 & $\begin{array}{c}1182.9 \\
89\end{array}$ & $\begin{array}{c}9488.4 \\
(190.92412 \\
)\end{array}$ & $\begin{array}{c}195.24 \\
(3.9285 \\
89)\end{array}$ & $\begin{array}{c}0.026 \\
4\end{array}$ & $\begin{array}{c}1.437 \\
140\end{array}$ \\
\hline
\end{tabular}

Notes: $y=$ yield per acre in Rs.(Dependent variable) $\mathrm{x}=$ interlinked loan (product linked loan) as a percentage of total loan taken (Independent variable)

Result: The regression co-efficient is positive in all the sample villages, implying a direct relationship between credit-product interlinkage and productivity However, $\mathrm{R}^{2}$ value is small in all villages.

credit-labour interlinkage and credit-product interlinkage is positive in all the sample villages, albeit its impact on productivity is not very strong. As such we cannot treat these sets of interlinkage as an important determinant of agricultural productivity.

The ground reality is that the introduction of new technique and technology in agriculture (since 1960s), i.e. introduction of HYV crops, better irrigation, use of chemical fertilizer and pesticides etc have helped to increase agricultural productivity. But this increased productivity has marginally been influenced by the present credit-labour and credit-product interlinkage system. With the improvement in agricultural activities, employment opportunities have been substantially increased and as a result, both the credit-labour and creditproduct interlinkage system have been weaned off. In the present socio-economic scenario, agricultural as well as non-agricultural activities have increased and hence demand for loan during lean period has been reduced substantially. Moreover, most of the farmers have reported that they do not usually give loan to the worker in view of the growing political interference and easy availability of migrated labour. At present they heavily depend on migrated labour especially during peak season. No landlord in the present socio-economic scenario can force anyone to repay the loan he has taken earlier. However, the loan in most cases is interest free and is not usually recovered by making any deduction from the wages earned by owing worker. Recently the formal sources of credit are becoming prominent and hence credit-product interlinkage is gradually getting weaker and weaker. Accordingly, its impact on productivity is no more significant. We may thus conclude that credit-labour and credit-product interlinkage has marginal impact on productivity in agriculture. Hence, a large number of determinants are responsible for the improvement of agricultural performance and interlinkage is one of them but its contribution is not very significant at present. The linkage effect of these factors on agricultural productivity is positive but it is losing its strength with time. 


\section{References:-}

[1] Bardhan, P. K. (1984):"Land Labour and Rural Poverty”,Essays in Development Economics, Oxford University Press.

[2] Gangopadhyay, S. and Sengupta, K. (1987) "Small Farmers, Money Lender and Training Activity" Oxford University Papers, 333-342.

[3] Bardhan, P.K. and Rudra. (1978), Bhaduri (1973)," Interlinkage on Land, Labour and Credit relations", An analysis of village survey data in East India, Economic and Political Weekly, 13, Annual Number, February..

[4] (4)Gangopadhyay, S. and Sengupta, K. (1987) " Small Farmers, Money Lender and Training Activity" Oxford University Papers, $333-342$.

[5] Bardhan, P. K. (ed): "The Economic Theory of Agrarian Institutions", Clarendon Press Oxford, 1989.

[6] Basu. K. (1984):“The Less Developed Economy”, A critique Contemporary Theory, Oxford Economic Press

[7] Bharadwaj, K. (1975): "Production Condition in Indian Agriculture", Cambridge University Press.

[8] Dutta, Santosh Kumar.(2002): “A Study of the Interlinkage in Agriculture”,Naya Udyog, Kolkata.

[9] Rudra, A. (1975): "Loans as a of Agrarian Relations", Some Results of a Preliminary Survey in West Bengal , Economic and Political Weekly,July 12.

[10] Shafi, M. (1965): “Approaches to the Measurement of Agricultural Efficiency”, Department of Geography, A.M.U., Aligarh.

[11] Boyce, J. K. (1987) : "Agrarian Impulse in Bengal", Institutional Constraints to Technological Change, Oxford University Press, New Delhi. 